\title{
FEATURE Working toward sustainable agricultural intensification in the Red River Delta of Vietnam
}

\author{
Lois Wright Morton
}

D

ense networks of rivers, canals, ditches, dikes, sluice gates, and compartmented fields have enabled the farms of the Red River Delta to produce $18 \%$ of Vietnam's rice (Oryza sativa) crop (figure 1), $26 \%$ of the country's vegetable crops, and $20 \%$ of capture and farmed aquaculture (Redfern et al. 2012). Agriculture in this fertile delta was transformed in the 11th and 13th century AD by large-scale hydraulic projects to protect the delta from flooding and saltwater intrusion, and provide field drainage during the wet season and crop irrigation in the dry season (Tinh 1999). The 20th century brought advancements in agricultural science globally - new crops and livestock genetics, inorganic fertilizers, mechanization, and pesticides that could double and triple food production per unit of land. It was the diesel pump combined with postVietnam War agricultural collectivization from 1975 to 1988 that brought the Green Revolution to the Red River Delta.

Yet the very success of this agricultural revolution capable of feeding more people brought unintended harm to the waters, soil, coastal mangrove forests, and delta ecosystems that made it all possible. Intensification of fish production destroyed wetland habitats; polluted waterways; and led to eutrophication, biotic depletion, and increased disease (Nguyen 2017; Ahmed and Thompson 2019). Exponential increases in shrimp (Penaeus monodon) farming devastated mangrove forests that protected against coastal erosion and mitigated the impacts of sea level rise (Joffre et al. 2015; Ahmed and Thompson 2019). Pesticide concentrations in soil and sediments were found to be high and persistent in rice fields (Braun et al. 2018).

The need to take the Green Revolution to the next level using innovation and technologies to create sustainable agricultural systems has never been greater. The Red River Delta faces a complex and difficult challenge: how to coproduce food systems that protect and conserve soil and water

\section{Figure 1}

The Green Revolution brought knowledge and technology innovations that have made Vietnam more food secure and a world leader in rice production. There is now a critical need to take the Green Revolution to the next level to achieve sustainable, resilient food systems and healthy ecosystems.

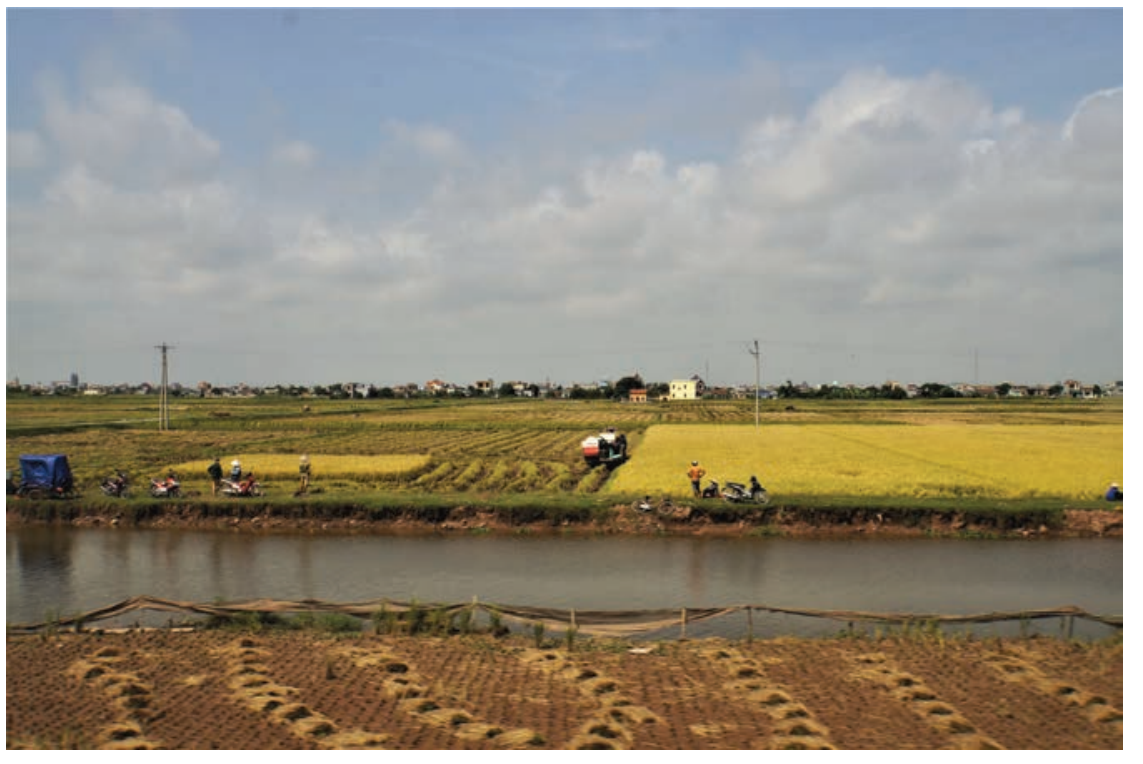

resources, provide nutrition and food security, and ensure robust livelihoods (Morton and Olson 2018). There is no more land to farm. Urbanization with its high land values is displacing delta agricultural land at alarming rates. Delta farmers must move to production systems that have increasing per unit of land efficiency without incurring net environmental costs (Pretty 2018). This means redesigning their systems for sustainable intensification (FAO 2017; Pretty 2018).

The goal of sustainable intensification is to make better use of human and natural resources such as land, water, biodiversity, knowledge, and technology (Pretty 2018). Efforts to develop new synergies among agriculture and its social-natural ecosystems are underway. Researchers are experimenting with redesign and transformation of agricultural systems using economic, social, and environmental sustainability metrics. The intent is to increase farmers' capacity to make informed decisions to adapt and transform their production systems to cope with the many internal and external pressures they face (Joffre et al. 2015; Solutions from the Land 2019). In this paper, the Red River Delta climate, soil, and water landscape are discussed followed by research on integrated systems; experiments in new technologies, practices, and tools; and policies that can help Vietnam move toward sustainable agricultural intensification.

THE RED RIVER DELTA, A WET LANDSCAPE Vietnam is a developing country with modernization goals and increasing investments in infrastructure, education, energy, and agricultural productivity. Hanoi, the capital city on the banks of the Red River, is located in the Red River Delta, (figure 2) where over 17 million people live on

Lois Wright Morton is professor emeritus of sociology, Department of Sociology, College of Agriculture and Life Sciences, lowa State University, Ames lowa.

Received March 4, 2020. 
$16,500 \mathrm{~km}^{2}\left(6,371 \mathrm{mi}^{2}\right)$ of land shaped by centuries of fluvial and coastal flooding (Bui et al. 2018). Economic reforms of 1986 transformed the agricultural sector and led to a dramatic decline in poverty from over $50 \%$ to currently $11 \%$ of the population below poverty (Goscha 2016). Economic development is heavily dependent on soil, water, forests, and other natural resources for agriculture, fisheries, forestry, and hydroelectric power.

Disasters in Vietnam are almost always water and climate related (Ninh et al. 2007). Like many river deltas around the world, this densely populated but very rural delta with productive soils is vulnerable to seasonal extremes in precipitation that lead to severe flooding and intraseasonal drought, storm surges, salinity incursions, changes in sediment transport and deposition, ground water depletion, and global sea level rise (Renaud et al.
2016; Tessler et al. 2015). Six to eight tropical storms occur annually with extensive and repeated damage to dikes, agricultural lands, fisheries, housing, roads, and other infrastructure (Ninh et al. 2007). Farmers as well as district, provincial, and national water managers face complex challenges in responding and adapting to emergency water crises and planning for future water management under weather uncertainties and a changing climate.

Almost half of the $169,000 \mathrm{~km}^{2}(65,251$ $\left.\mathrm{mi}^{2}\right)$ Red River basin is located in the mountains of Yunnan Province, China, where the Red River originates. Three major tributaries, the Black (Da), Thao, and Lo rivers, flow off the mountains and uplands of China and Vietnam bringing flood waters into the Red River and its delta (Dang et al. 2011). In recent years four dams and reservoirs (Hoa Binh, Thac Ba, Tuyen Quang, and Son $\mathrm{La}$ ) with 8.5 billion $\mathrm{m}^{3}$ (300 billion

\section{Figure 2}

Map of Red River Delta, Vietnam, with the location of mangrove forests grown along the delta coastline as shelterbelts that dissipate wave energy, reduce coastal erosion, capture and retain sediments, maintain water quality, provide wetland habitats and fishery nurseries, and assist in adapting coastal lands to sea level rise. Graphic design by Cruz Dragosavac.

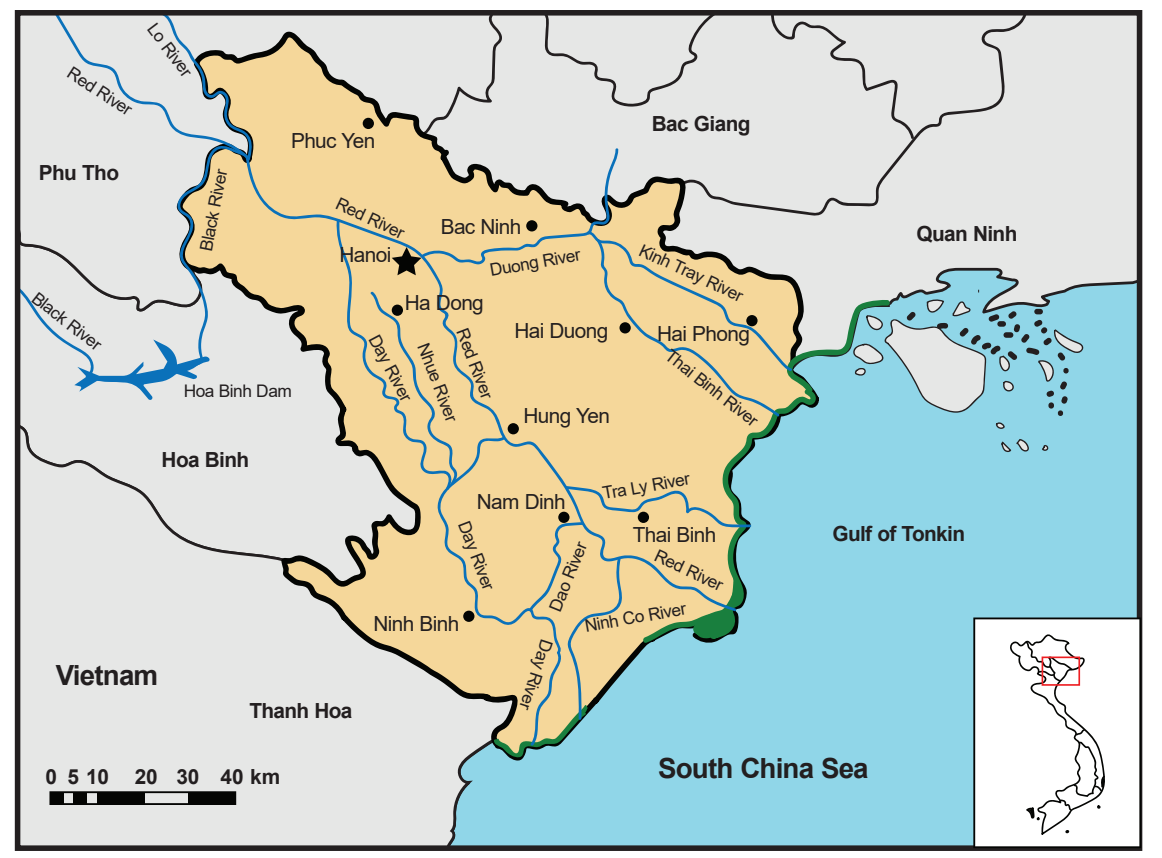

Legend

Mangrove forest

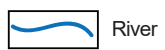

Red River Delta

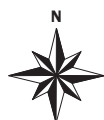

$\left.\mathrm{ft}^{3}\right)$ total water storage capacity were built to control flooding. Upstream $35 \mathrm{~km} \mathrm{(22}$ mi) from Hanoi, a flood diversion was built in the Day River Basin in 1937. Since the 1989 completion of the Hoa Binh dam on the Black River (figure 2) at the interface of the plateau region and the delta, there have been no flood events that required opening of the Day River Flood Diversion (Dang et al. 2011).

The Red River Delta at $21^{\circ} \mathrm{N}$ latitude has a subtropical climate with an annual average temperature of $23.5^{\circ} \mathrm{C}\left(74.3^{\circ} \mathrm{F}\right)$ and mean annual rainfall $1,667 \mathrm{~mm}(65.6$ in) of which three-quarters falls May to October, the monsoon wet season (Braun et al. 2018).Variations in temperature and precipitation are represented by three distinct seasons: a cool, dry season (October to January); a cool, humid season (February to April); and the monsoon season that is hot and wet (May to September [Huong et al. 2013]). Although agriculture is a yearround endeavor, the characteristics of each season, precipitation, soil, and typography influence the selection of crops planted.

The delta topography-lowlands, midlands, and highlands - is best understood in relation to water levels and risks of flooding associated with the season. The lowlands without dikes would be under water in the rainy season due to runoff and bank overflow during flooding. Primarily clayey soils, lowlands are always wet and marshy even in the dry season if not drained, and high tide would flood much of the delta if the lowlands were not protected by dikes (Devienne 2006). Midlands are found along the coastal, eastern, and central parts of the delta. Without dikes the midlands would typically be submerged by monsoon flooding, and salt water intrusion into rivers, canals, and ditches during the dry season would severely damage agricultural crops. The highlands in the northern and central delta consist of sandy soils, natural levee deposits from historic Red River flooding, and do not flood.

\section{MANAGING A WET LANDSCAPE}

Vietnam's remaking of delta landscapes to protect against river and coastal sea flooding is not a new phenomenon (Olson and Morton 2018). River dikes were built in 1108 AD to protect the Dai La King's 
town (Hanoi), and by the 13th century dikes ran the length of the Red River from Viet Tri, upstream of Hanoi, to its mouth at the South China Sea with sea dikes along the coast (Tinh 1999). Today, 3,000 $\mathrm{km}(1,864 \mathrm{mi})$ of sea dikes and $5,000 \mathrm{~km}$ $(3,107 \mathrm{mi})$ of river dikes with sluice gates (figure 3) regulate the many rivers, ditches, and canals that flow throughout the Red River Delta (Braun et al. 2018) and protect coastal lowlands from the sea.

Typhoons and storm surges flood lowlying areas, destroy sea dikes, and accelerate coastal erosion with waves $1.5 \mathrm{~m}(5 \mathrm{ft})$ to over $2.5 \mathrm{~m}$ (8.2 ft). Local and global climate change and rising sea levels have renewed efforts to reestablish and maintain a living seawall of mangrove forests along Vietnam's coast (figure 2). Mangrove forests with their tangled roots in the silty clay low-oxygen $\left(\mathrm{O}_{2}\right)$ soils of delta and coastal estuaries can take as much as $50 \%$ of the energy out of storm surges (Veettil et al. 2019). Their complex aerial root structures capture fine soils and river sediments, reduce rates of coastal erosion, contribute to delta building, and mitigate climate change sea level rise effects (Besset et al. 2019).

The flood season (June to October with serious flooding in August) finds water levels up to 4 to $8 \mathrm{~m}$ (13 to $26 \mathrm{ft}$ ) higher than the natural ground level. Routine maintenance and vigilant scouting for weakness in the dike system are critical to prevent breaching during floods. The early network of dikes, ditching, and canals to prevent flooding depended on gravity flow. This created a new problem: fields could not be easily drained or irrigated.

The introduction of vaulted aqueducts and sluice gates (figure 3) for draining and irrigation made it possible to open the gates during drought and close them during the fifth or tenth month when crops were growing and susceptible to flooding. During high water season, diked rivers are higher than the low-lying areas, and drainage cannot occur while the sluice gates are closed. As a result, prior to diesel pumps, vast lakes formed behind the dikes. During the wet season, locally each farmer built ponds/arroyos and filled them with the natural flow of the river (Olson and Morton 2018). Farmers used these ponds during dry periods to irri-

\section{Figure 3}

Sluice gates regulate the flow of water in canals, rivers, and ditches. Fast rises in water levels during rain events with high runoff can be managed by closing the sluice gates. Opening the gates permits excess water to be drained from fields, and closing them during the dry season can prevent salt water intrusion, especially at high tides.

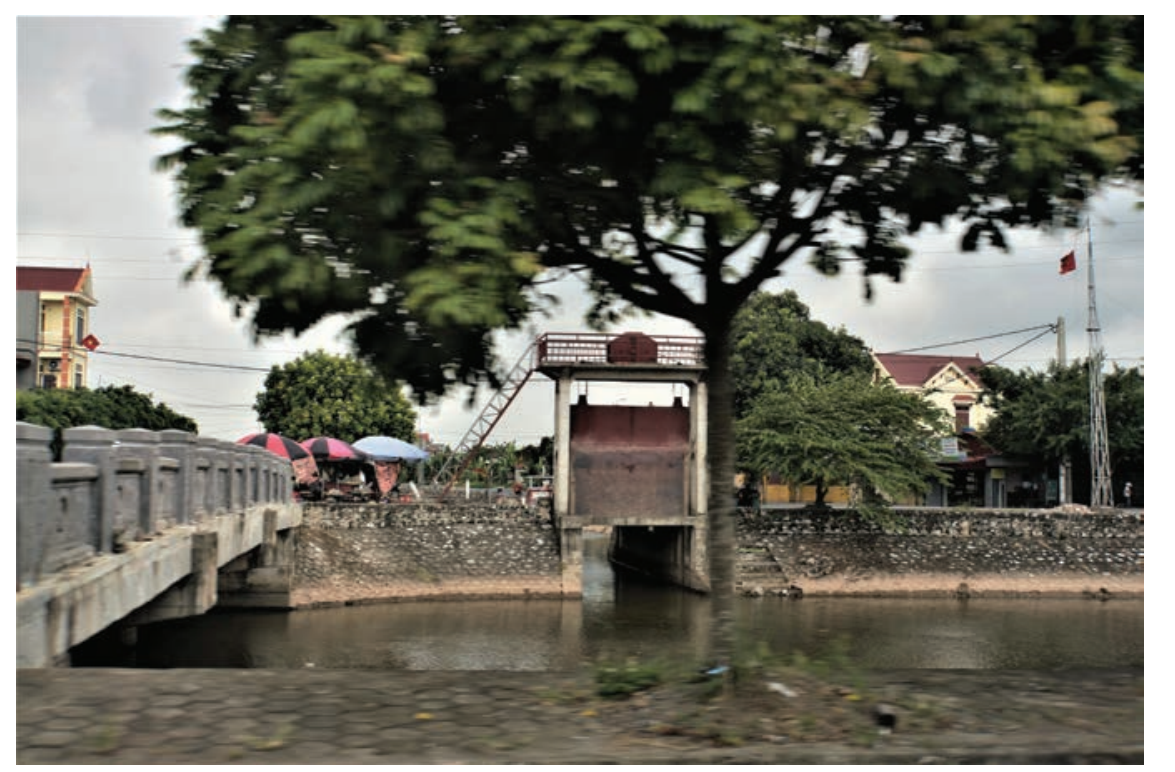

gate plots using a bailing process to pour water directly into the rice field or into a ditch that flowed into fields.

Pumping stations and mobile diesel pumps transformed the gravity-fed drainage network by stabilizing water flows (figure 4). It became possible to lower water levels inside the compartments during the wet season and raise the water level for irrigation during the dry season. Stabilizing water flows led to an unintended consequence as surface water pollution and high concentrations of pesticides in irrigation water and rice paddy soils are not diluted by fresh running water but are trapped (Braun et al. 2018). Thus, while dikes and sluice gates create closed systems to protect agricultural lands from flood and storms, they tend to concentrate pesticides and reduce sediment flows into rice paddies that historically restored soil fertility.

Recent research has examined the impact of year-round pesticide use in rice paddies downstream near the mouth of the Red River. Soil and sediment sampling revealed all soil samples in rice paddies had a minimum of three pesticides present with some showing as many as eight different pesticides in a single sample
(Braun et al. 2018). Isoprothiolane (World Health Organization [WHO] classification II toxic) is a fungicide found in all soil samples at the study site. Eighty-five percent of the soil samples had the insecticide chlorpyrifos (WHO class II toxic) present and the highest residue concentration of the top three pesticides. The silty clay loam of the rice paddies ranged from $\mathrm{pH} 5.9$ to 6.1 and soil organic carbon (SOC) from 15.6 to $19.3 \mathrm{~g} \mathrm{~kg}^{-1}$ ( 7.7\% to $11 \%$ ) (Braun et al. 2018). The high residue concentration of chlorpyrifos can be explained by its strong sorption to organic matter.

Braun et al. (2018) recommend holding the water in rice fields for at least 10 days after pesticide application to reduce discharge concentrations into canals and irrigation ditches and limit pesticide pollution. They also recommend using integrated pest management (IPM) to reduce applications and to pay close attention to pesticide application timing with the opening of the outlet sea sluice to discharge irrigation water. This can reduce the pesticide load in the single pulse of suspended sediment and lower the effect on mangrove forests and clam farms outside the sea dike near the open gate. 


\section{AGRICUTLURAL INTENSIFICATION, LIVELIHOODS, RICE, AND AQUACULTURE}

Post-1975 collectives were the entry point for new cultivars, fertilizers, and pesticides needed for increasing yields. More importantly, collectives provided centralized hydraulic planning and dike construction, and equipped the entire water network with powerful pumping stations that drained and irrigated the delta landscape (Devienne 2006). However, despite enormous investments in modern drainage, the cooperative agricultural production system failed to realize the yields and profits that agricultural intensification promised (Goscha 2016; Devienne 2006). It was not until the 1980s when land reform laws gave individual households their own land and autonomy to make their own crop production and marketing decisions that agricultural intensification increased productivity and improved rural livelihoods. As a result,Vietnam increased food security and became a major rice exporter (Goscha 2016). This economic doi moi (renovation) of the agricultural sector encouraged private entrepreneurship, ownership, and market-based incentives that revived production and transformed Vietnam agriculture (Goscha 2016). Today Vietnam produces about $3,700 \mathrm{ha}(9,143 \mathrm{ac})$ of irrigated rice and almost 2,000 ha $(4,942 \mathrm{ac})$ of rainfed rice (Redfern et al. 2012).

The temperatures in the Red River Delta are favorable for double and triple cropping of rice, year-round vegetable production, animal husbandry, and freshwater and salt water aquaculture. A market economy has brought the freedom to choose and modify systems of production to meet household needs and market demands. Household farms are very small scale. The average Red River Delta farm is about $2,700 \mathrm{~m}^{2}\left(29,062 \mathrm{ft}^{2}\right)$, or a little less than 1 ha $(<2.5 \mathrm{ac})$, with the average size of a vegetable plot $400 \mathrm{~m}^{2}\left(4,305 \mathrm{ft}^{2}\right)$ (Huong et al. 2013).

Sustainable agricultural production means households need resources, knowledge, skills, and technologies to manage production, environmental, and economic risks. Even at small scales, decision making is complex: managing irrigation and drainage, crop inputs, labor, pest scouting and pesticide applications, weather, markets, and

\section{Figure 4}

The introduction of diesel pumps transformed water management of clam, mussel, shrimp, and fish ponds and stabilized drainage and irrigation of rice and vegetable crops grown in diked compartmented fields.

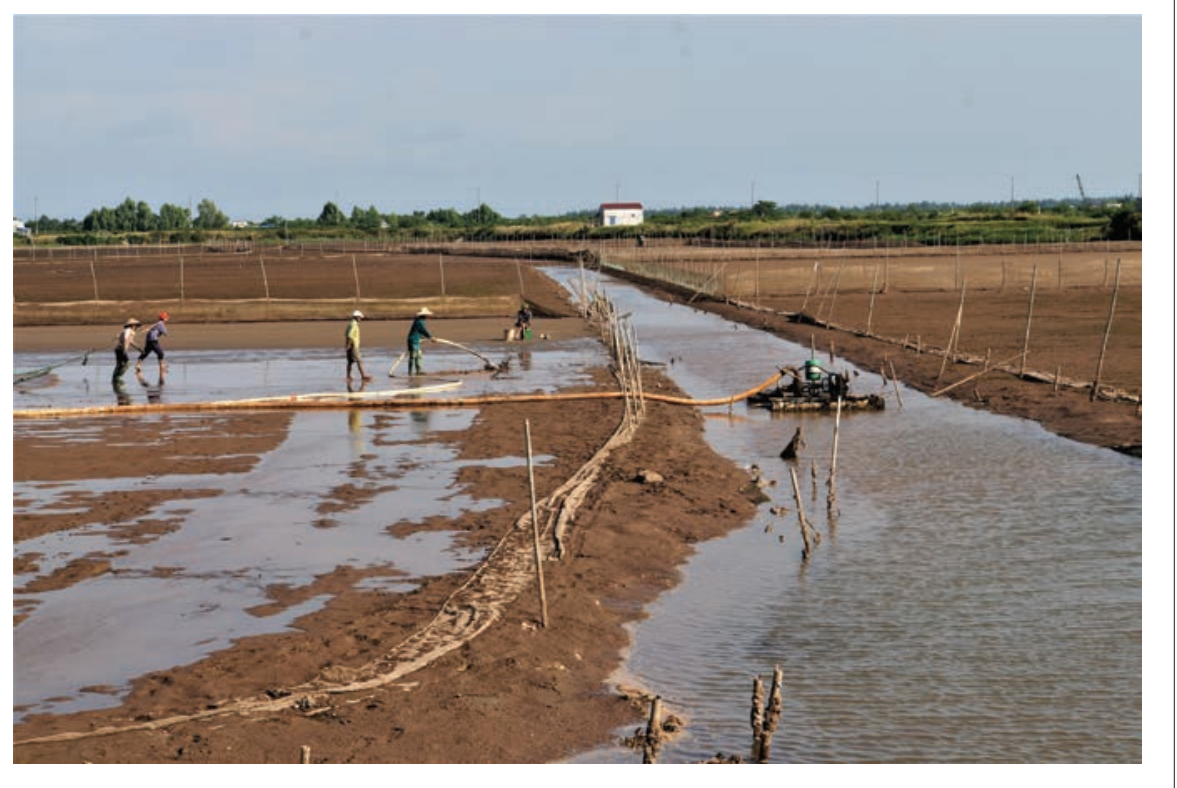

variable prices with the season. One of the biggest trade-offs small plot households face is ensuring household food security while specializing in market crops that can provide livelihoods (Morton and Olson 2018). FAO (2017) reports that the rural poor of Southeast Asia who remain in rural areas are more likely to escape poverty than those who migrate to urban areas. The agricultural diversity of the small farm grounded in traditional rice-fish/animal-garden components is one explanation of why households may be poor but nutrition and food secure. The challenge for rural farmers and agricultural-supporting infrastructure policies is how to sustainably increase the productivity of small landholdings, conserve soil and water resources, increase the diversity of household income streams, and ensure food security.

Rice is the staple cereal crop for Vietnam households and an important export commodity. Production grew more than $25 \%$ from 2000 to 2011 without increases in rice acreage, primarily due to intensified cropping practices involving new rice varieties, irrigation during the dry season, and increases in fertilizer and pesticides (Kontgis et al. 2015). Shorter season and higher yielding varieties in conjunction with irrigation during the dry season have enabled two and three crops to be produced annually. Flooded rice production is well suited to the delta soils and the extensive dike and compartment system that controls water levels during transplant, growing, and harvest periods. However, water degradation and pollution from agricultural chemicals and prediction of $1 \mathrm{~m}(3.3 \mathrm{ft})$ rise in sea level threaten the agronomic and environmental sustainability of rice (Redfern et al. 2012). Changes in sea level will alter inland tidal movements, sediment transport and discharge, and shoreline gradients as well as stress the hydraulic infrastructure, increase saline intrusion, and flood populations who live in the delta lowlands (Redfern et al. 2012).

Saline-tolerant, high yielding rice varieties are currently under development and will be needed along with varieties that can withstand longer submergence during the growing season especially in coastal rice growing areas of the delta where saline intrusion into fresh water rivers is increasing. Site-specific nutrient management, IPM, crop rotations, use of crop residues, deep placement of urea, and a new system of rice intensification are practices and technologies shown to be effective in addressing the 
negative environmental effects of intensive rice production (Redfern et al. 2012). However, these practices and technologies require that information, education, and training be systematically available to delta farmers along with financial resources to implement them.

\section{AQUACULTURE}

Prior to the 1986 land reform, wetlands were considered common property. Since then, the clearing of mangrove forests and conversion to aquaculture has transformed coastal and inland wetlands into fish, shrimp, crab, and clam ponds (figure 4) (Veettil et al. 2019). Those who cleared mangroves to construct shrimp ponds were exempt from tax to the cooperative for the first five years (Pham and Yoshino 2016). Aquaculture brings in more household income than rice but as a high value monocrop is risky and vulnerable to supply-demand price extremes (Huong et al. 2018; Joffre et al. 2015).

Intensive shrimp farming with profit maximization goals have high stocking densities, are mechanically aerated, require chemical inputs, and have a single harvest per crop cycle (Joffre et al. 2015). Risk management in intensive systems is dependent upon a closed system and efforts to manage water quality in the ponds to avoid disease-related infections (Joffre et al. 2015). The water $\mathrm{pH}$ for shrimp aquaculture is species dependent with some doing best in slightly alkaline water up to 7.5 and others doing best in acidic water $\sim 6.5$. Similarly, species vary in suitable water temperatures, from $21^{\circ} \mathrm{C}$ to $24^{\circ} \mathrm{C}\left(70^{\circ} \mathrm{F}\right.$ to $\left.75^{\circ} \mathrm{F}\right)$. The most critical aspect of shrimp production is that water temperatures and $\mathrm{pH}$ are consistent; sudden shocks to the shrimp habitat can be fatal.

Profits from aquaculture have been considerable. However, intensive aquaculture profitability is short-lived as pond water is quickly degraded. Managing for optimum production creates serious adverse effects including water contamination and increased salinization of soils and groundwater (van Wesenbeeck et al. 2015). Large companies abandon the ponds when profits decrease and seek out new pond locations where water quality is better (van Wesenbeeck et al. 2015).
Rapid conversion of mangrove forests into shrimp and fish ponds has been a big threat to the coastal environment (van Wesenbeeck et al. 2015). Loss of mangroves have a cascading effect, increasing land subsidence, which makes the coastline increasingly vulnerable to erosion as water depths and wave heights increase. Pond embankments reflect rather than dissipate waves and undermine shrimp enclosures thereby disrupting stable salinity levels within the pond. Farm-level changes influence the resilience of entire coastal landscapes. The sustainability of a shrimp farm depends on the farmer's knowledge; management decisions; and capacity to quickly respond and adapt to climate, water, and salt intrusion disruptions and shocks while paying attention to the ecological system surrounding the farm (Joffre 2015).

\section{INTEGRATED AGRICULTURE}

To manage risk, many small-scale farmers in the Red River Delta integrate aquaculture with other crops to create diversified variations of a system calledVAC: garden (Vuon) vegetable and orchard crops, fish pond $(A o)$, and livestock pen (Chuong) in addition to rice production (Huong et al.2018). Huong et al. (2018) analyzed four variations of this diverse system that expands traditional subsistence agriculture to create marketable surplus by increasing proportions of land allocated to aquaculture.

The most basic, smallest-scale integrated VAC system typically within a rural village has on average $<4,000 \mathrm{~m}^{2}(<1 \mathrm{ac})$ of agricultural land and includes low-input aquaculture in a $878 \mathrm{~m}^{2}\left(9,451 \mathrm{ft}^{2}\right)$ pond; $2,812 \mathrm{~m}^{2}\left(30,268 \mathrm{ft}^{2}\right)$ of paddy rice; 131 $\mathrm{m}^{2}\left(1,410 \mathrm{ft}^{2}\right)$ of orchards; and 5 to 15 pigs. These households are more likely to supplement farm income with off-farm income than those integrated systems with a larger proportion of their production system in aquaculture. Three other integrated aquaculture systems are found outside of rural villages and are producing on larger plots ranging on average from 4,212 $\mathrm{m}^{2}$ $\left(45,338 \mathrm{ft}^{2}\right.$; new VAC system) to $6,732 \mathrm{~m}^{2}$ $\left(72,463 \mathrm{ft}^{2}\right.$; fish system) of agricultural lands. The fish-pig/poultry system on $6,588 \mathrm{~m}^{2}$ $\left(70,913 \mathrm{ft}^{2}\right)$ has major inputs in the form of feeds and veterinary supplies. The commercial fish system is intensively focused on fish, often having two ponds, a fingerling nursery, and a rearing-to-harvest pond with on average the smallest space allocated to rice $\left(1,512 \mathrm{~m}^{2}\left[16,275 \mathrm{ft}^{2}\right]\right)$ primarily for household consumption.

The fish system offers the highest economic return of the four systems, but has the lowest aquaculture yield compared to the traditionalVAC that has more than six species of fish. Although the traditional VAC system is the smallest scale of production, it is the most productive model with a nutrient feeding flow that recycles grass carp waste to benefit other species in the fish pond (Huong et al. 2018). The fish and animal-fish systems are sources of higher household income; the traditional VAC and new VAC systems contribute significantly to in-kind household food security and nutrition.

\section{VEGETABLES}

More than a quarter of Vietnam agricultural land is in vegetable production (figure 5) and the source of $30 \%$ of the country's vegetables (Huong et al. 2013). Increasing year-round demand for vegetables in urban food markets offer opportunities for farmers to specialize in high value vegetable crops and improve soil properties after rice production (Everaarts et al. 2015). Limits to household farm size make specialty crops attractive to farmers enabling them to intensify per unit of land use with a crop that typically brings higher income than rice.

Research is showing that a two-year cycle of vegetables following flooded rice production can increase household per hectare income and improve soil structure. Wet and flooded soil conditions of rice production called "puddling" create a compacted soil layer 18 to $25 \mathrm{~cm}$ (7 to 10 in) just below the rice roots. This compacted layer prevents water from draining out of the field, a benefit for rice production but a major problem for vegetables grown after flooded rice. The soil structure improves considerably when the rice-vegetable rotation moves to a "permanent" two-year 8 to 17 vegetable crop sequence (Huong et al. 2014). Seasonal temperatures and precipitation determine crops selected, planting and harvest timing, pest management, and irrigation/drainage practices. The complexity of selecting 


\section{Figure 5}

Vietnam's climate is well suited to grow a variety of high value vegetables year round. New tools are being developed to help farmers plan complex field vegetable crop sequences and rotations to meet their unique labor, biodiversity, lower pesticide use, perishability, market timing, and profitability goals.

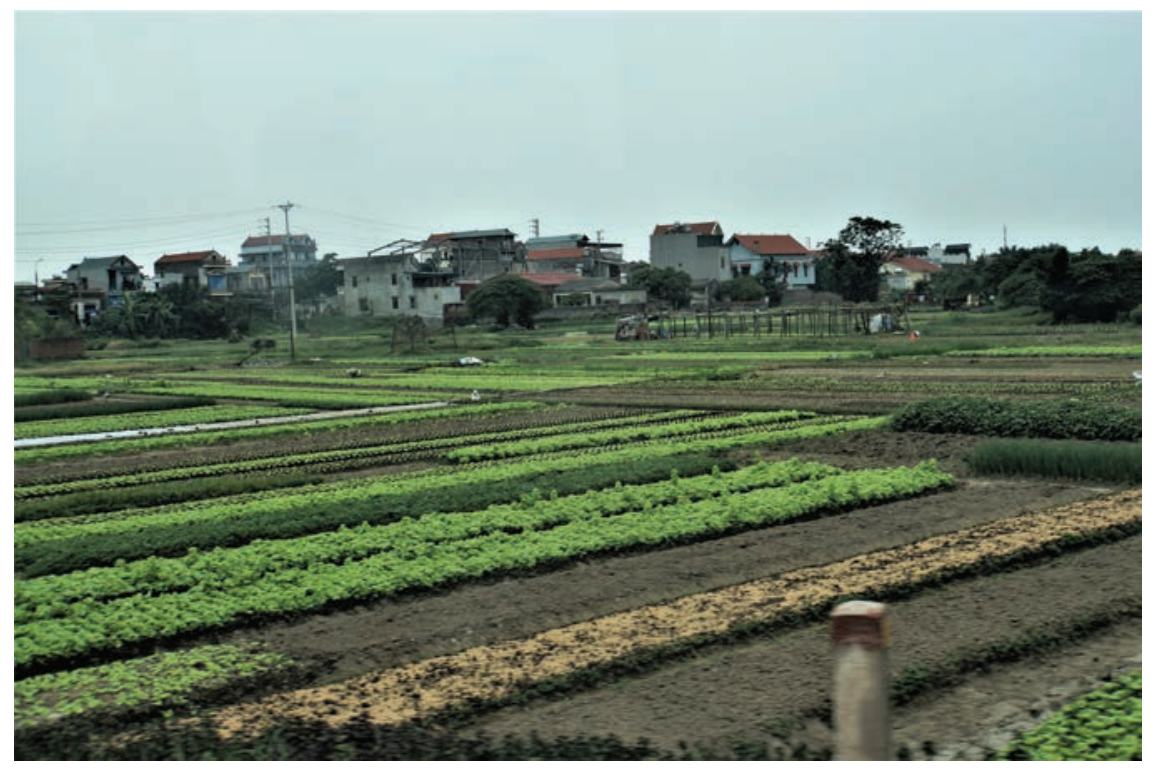

and sequencing high value vegetable crops based on these variables as well as storage and transportation infrastructure can be challenging to farmer decision making.

Data inputs necessary to determine best scenarios are not static-market prices, pesticide needs, soil conditions, temperature and precipitation variability, and many other information inputs continually change. PermVeg is a new tool farmers and their advisors can use in planning their vegetable crop sequences based on current conditions and farm priorities. Experiments on vegetable crop selection and sequencing used the PermVeg tool to evaluate five different systems based on preference for specific outcomes: (1) highest income, (2) lowest labor input but equal to/greater than mean profitability, (3) lowest pesticide use but equal to/ greater than mean profitability, (4) high diversity using high profit crop selections, and (5) low perishability (quality retained four days after harvest) and high profit (Huong et al. 2014). Simulation results show three times the profit per hectare per day compared to the traditional vegetables following flooded rice rotation.

These findings are congruent with the United Nations Food and Agriculture
Organization report that declining farm size does not necessarily hinder productivity (FAO 2017); while labor productivity is low, small farms have the highest per unit land productivity. However as small farms become even smaller and fragmentation of the landscape occurs, small producer capacity to successfully adopt sustainable intensification productivity technologies and be market oriented will be limited by scale and integration into the modern value chain (FAO 2017).

\section{PROGRESS TOWARD SUSTAINABILITY}

Vietnam has invested considerable resources to manage and redistribute water and ensure agricultural productivity, food security, and improved rural livelihoods. The unintended side effects of these investments are degradation of the delta's soil and water resource capacity to continue to effectively support agricultural intensification and small and mid-scale farmer livelihoods. Resource use assessments of the Vietnam shrimp industry predict a 50\% increase in demand for fisheries products (Boyd et al. 2017). Farm-level assessments of shrimp production in Vietnam and Thailand conclude that water, energy, and land use decrease as farm production intensity increases (Boyd et al. 2017). However, there is a critical need to address the negative environmental impacts intensified aquaculture has on water quality and loss of coastal wetland habitats. Overfishing of wild fish and rapid expansion of aquaculture need fisheries standards, policies, laws, regulation, and enforcement to reduce water pollution, prevent soil erosion, protect mangrove forests, and incentivize sustainable management practices (Nguyen 2017).

By definition, sustainability requires the coproduction of agricultural productivity, ecosystem integrity, and economic well-being. Aquaculture sustainable intensification will depend on innovation, technologies, and farm level management changes that involve solid waste and wastewater treatment systems; more efficient mechanical aeration equipment and usage; pond rotations; and water recirculation systems that use less water and reduce disease transmission from external sources (Boyd et al. 2017; Nguyen 2017). Increased farmer knowledge of disease and environmental risks coupled with more efficient management of stocking densities, use of polycultures (e.g., shrimp with tilapia), replacement of wild fishmeal in shrimp feed with animal byproducts or plant meals, and integrated rice-shrimp systems are scientifically tested strategies for increasing sustainable productivity (Boyd et al. 2017; Nguyen 2017).

New research and efforts to move Vietnam farmers into high value and integrated systems that utilize sustainable intensification approaches show promise to address environmental and profitability concerns while increasing food production. The shift from rice-only cropping to a variety of integrated high value crops entails a redesign of farm cropping systems and land uses. Vegetable production systems with crop sequences of 8 to 17 crops over a two-year period enable farmers to diversify crops and provide high quality, nutritious foods (Huong et al. 2013). Crop rotations can reduce disease pressure and pesticide use, recycle nitrogen $(\mathrm{N})$ and other nutrients, and allow farmers to select high value crops for particular traits related to growing conditions and market demand. A shift from aqua-monoculture to inte- 
grated livestock-fish-fruit/orchard-rice systems gives farmers unique flexibility to select and produce high value crops that conserve soil and water resources, offer income diversity, and address minimum household food security.

Red River Delta agriculture has new opportunities to transform itself with the growing demand from higher income urban consumers whose diets are moving away from rice toward high value fish, meat, eggs, vegetables, and fruits. To ensure that the matrix of all scales of farms are able to participate in meeting this urban food demand, there is a need for policies that reduce barriers to accessing inputs and encourage adoption of environmentally sustainable approaches and technologies. All farmers need strategies that reduce the uncertainties and risks of crop loss and market failures while maximizing available resources in ways that achieve sustainability. Global and national consolidation of input markets favor larger and more commercialized farms, which benefit from economies of scale in purchase of quality seed, high yielding hybrid varieties, equipment, and technologies. This has left smaller scale farmers behind as infrastructure and institutional arrangements and policies (lack thereof) often limit access to technologies and markets (FAO 2017).

Interventions to address market failures and enable small- and medium-scale farms to sustainability intensify their operations include access to affordable rural advisory and technical extension services; involvement in on-farm research experiments to increase knowledge about delta agroecosystems and practices that can reduce environmental degradation; and support for farmer cooperative purchasing, production, and marketing (FAO 2017). There is a need for small-farm technologies, mechanization, and equipment design appropriate to land holding scale that increases labor and land productivity. Farmers also need information and communication technologies for purchasing inputs and to learn about production alternatives and market opportunities. In some rural locales, growth of agro-industry is held back by lack of/reliability of electrical power grids for refrigerated storage and refrigerated transportation to hold product quality as well as a need for transportation infrastructure improvements linking rural supply chains to urban markets.

\section{CONCLUSION}

Sustainable intensification is explicit about the environmental, social, and economic profitability balance that is necessary to create sustainable local, regional, and global earth systems.

The transition toward sustainability will happen in nonlinear ways as farmers and their value chains move beyond efficiency (e.g., better management) to substitution (e.g., new hybrids, soil and water conservation technologies) and redesign (e.g., different cropping systems and landscape uses) (Pretty 2018). Taking the Green Revolution to the next level will require innovative substitution and redesign strategies that maximize the coproduction of agricultural productivity, beneficial environmental outcomes, and robust rural livelihoods (Morton and Olson 2018). Sustainable agricultural intensification is one of the approaches the United Nations recognizes as a way to successfully achieve 10 of the 17 Sustainable Development Goals of good health and wellbeing; zero hunger (via agricultural productivity); clean water and sanitation; life below water; life on land (via better management of soil, water, and ecosystems); decent work and economic growth; no poverty (via profitability and rural livelihoods); responsible production and consumption; industry, innovation, and infrastructure (technologies for all scales of agriculture); and climate action (FAO 2017).Vietnam is making progress toward sustainable agricultural systems.

\section{ACKNOWLEDGEMENT}

Published with support from Iowa Agriculture and Home Economics Experiment Station, College of Agriculture and Life Sciences at Iowa State University, Ames, Iowa.

\section{REFERENCES}

Ahmed, N., and S.Thompson. 2019. The blue dimensions of aquaculture: A global synthesis. Science of the Total Environment 652:851-861.

Besset, M., N. Gratiot, E.J. Anthony, F. Bouchette, M. Goichot, and P. Marchesiello. 2019. Mangroves and shoreline erosion in the Mekong River delta,
Vietnam. Estuarine, Coastal and Shelf Science 226:106263.

Boyd, C.E., A.A. McNevin, P. Racine, H.Q. Tinh, H.N. Minh, R. Viriyatum, and D. Paungkaew. 2017. Resource use assessment of shrimp, Litopenaeus vannamei and Penaeus monodon, production in Thailand and Vietnam. Journal of World Aquaculture Society 48:2:201-224

Braun, G., Z. Sebesvari, M. Braun, J. Kruse, W. Amelung, N.T. An, and F.G. Renaud. 2018. Does sea-dike construction affect the spatial distribution of pesticides in agricultural soils? A case study from the Red River Delta, Vietnam. Environmental Pollution 243:890-899.

Bui,V., D. Fan, D.V. Nguyen, D.L. Tran, D.T. Tran, V.L. Hoang, and T.H.H. Nguyen. 2018. Morphological change in the Northern Red River Delta, Vietnam. Journal of Ocean University of China 17:1272-1280.

Dang, N.M., M.S. Babel, and H.T. Luong. 2011. Evaluation of food risk parameters in the Day River Flood Diversion Area, Red River Delta, Vietnam. Natural Hazards 56:169-194.

Devienne, S. 2006. Red River Delta. Fifty years of change. Moussons 9-10, Agriculture in Southeast Asia. https://doi.org/10.4000/moussons.2042.

Everaarts, A.P., J.J. Neeteson, P.R.R. Huong, and P.C. Struik. 2015. Vegetable production after flooded rice improves soil properties in the Red River Delta,Vietnam. Pedosphere 25(1):130-139.

FAO (Food and Agriculture Organization of the United Nations). 2017. The State of Food and Agriculture 2017. Rome, Italy: Food and Agriculture Organization of the United Nations. Goscha, C. 2016.Vietnam. A New History. New York: Basic Books.

Huong, N.V., T.H Cuong, T.T.N.Thu, and P. Lebailly. 2018. Efficiency of different integrated agriculture aquaculture systems in the Red River Delta of Vietnam. Sustainability 10(2):493.

Huong, P.T.T., A.P. Everaarts, J.J. Neeteson, and P.C. Struik. 2013. Vegetable production in the Red River Delta of Vietnam: Opportunities and constraints. NJAS Wageningen Journal of Life Sciences 67:27-36.

Huong, P.T.T., A.P. Everaarts, W. vanden Berg, J.J. Neeteson, and P.C. Struik. 2014. PermVeg: A model to design crop sequences for permanent vegetable production systems in the Red River Delta, Vietnam. Journal of Agronomy and Crop Science 200:301-316.

Joffre, O.M., R.H. Bosma, A.K. Bregt, P.A.M. van Zwieten, S.R. Bush, and J.A.J. Verreth. 2015. What drives the adoption of integrated shrimp 
mangrove aquaculture in Vietnam? Ocean and Coastal Management 114:53-63.

Kontgis, C., A. Schneider, and M. Ozdogan. 2015. Mapping rice paddy extent and intensification in the Vietnamese Mekong River Delta with dense time stacks of Landsat data. Remote Sensing of Environment 169:255-269.

Morton, L.W., and K.R. Olson. 2018. The pulses of the Mekong River Basin: Rivers and the livelihoods of farmers and fishers. Journal of Environmental Protection 9(4):431-459.

Nguyen, C.V. 2017. An overview of agricultural pollution in Vietnam: The aquaculture section. Washington, DC: World Bank.

Ninh, N.H., V.K. Trung, and N.X. Niem. 2007. Flooding in Mekong River Delta, Vietnam Human Development Report 2007/2008. New York, NY: United Nations Development Programme. http://hdr.undp.org/sites/default/ files/nguyen_huu_ninh.pdf.

Olson, K.R., and L.W. Morton. 2018. Polders, dikes, canals, rice, and aquaculture in the Mekong Delta. Journal of Soil and Water Conservation 73(4):83A-89A. https://doi.org/10.2489/ jswc.73.4.83A.

Pham, T.D., and K. Yoshino. 2016. Impacts of mangrove management systems on mangrove changes in the Northern Coast of Vietnam. Tropics 24(4):141-151.

Pretty, J. 2018. Intensification for redesign and sustainable agricultural systems. Science 362, eaav0294. DOI: $10.1126 /$ science.aav0294.
Redfern, S.K., N. Azzu, and J.S. Binamira. 2012. Rice in Southeast Asia: Facing risk and vulnerabilities to respond to climate change. Food and Agriculture Organization of the United Nations/ Organization for Economic Cooperation and Development Workshop, April 23-24, 2012.

Renaud, F.G., S. Szabo, and Z. Matthews. 2016. Sustinable deltas: Livelihoods, ecosystem services, and policy implications. Sustainable Science 11:519-523.

Solutions from the Land. 2019. Guiding Principles for the Koronivia Joint Work on Agriculture. North America Climate Smart Agriculture Alliance (NACSAA). Lutherville, MD: Solutions from the Land. https://www.sfldialogue.net/.

Tessler, Z.D., C.J. Vorosmarty, M. Grossberg, I. Gladkova, H. Aizenman, J.P.M Syvitski, and E. Foufoula-Georgiou. 2015. Profiling risk and sustainability in coastal delta of the world. Science 349(6248):638-643.

Tinh, D.Q. 1999.Vietnam Country Report 1999. Asian Disaster Reduction Center. https://www.adrc.asia/. van Wesenbeeck, B.K., T. Balke, P. van Eijk, R. Tonneijck, H.Y. Siry, M.E. Rudianto, and J.C. Winterwerp. 2015. Aquaculture induced erosion of tropical coastlines throws coastal communities back into poverty. Ocean and Coastal Management 116:466-469.

Veettil, B.K., R.D. Ward, N.X. Quang, N.T.T. Trang, and T.H. Giang. 2019. Mangroves of Vietnam: Historical development, current state of research and future threats. Estuarine, Coastal, and Shelf Science 2018:212-236. 